\title{
WEBSITE QUALITY, BRAND IMAGE, DAN E-WOM SERTA PENGARUHNYA TERHADAP ONLINE PURCHASE INTENTION STUDI PENGUNJUNG WEBSITE BERRYBENKA
}

\author{
Lutfi Indana \\ Universitas Negeri Surabaya \\ lunaindana@gmail.com \\ Anik Lestari Andjarwati \\ Universitas Negeri Surabaya \\ aniklestari@unesa.ac.id
}

\begin{abstract}
The high purchasing power of the people for fashion products is an opportunity for the company to create new business strategies to compete. One of the fashion brands in Indonesia is Berrybenka, which offers a variety of the latest and high-quality fashion needs. However, in consumer purchases made online through websites, there are still negative reviews about Berrybenka. This study aims to analyze the effect of website quality, brand image, and e-WOM on online purchase intentions. This study is focused on Berrybenka websites visitors as a sample with a nonprobability sampling technique. The questionnaire was taken to 200 respondents using a Likert scale. The data analysis technique used multiple linear regression. The results showed that website quality, the brand image had an influence on online purchase intentions and e-WOM had no effect on online purchase intentions.
\end{abstract}

Keyword: brand image; e-WOM; fashion; online purchase intention; website quality

\section{PENDAHULUAN}

Penduduk Indonesia rata-rata menghabiskan hampir delapan jam perhari untuk mengakses internet (Jayani, 2020). Menurut Asosiasi Penyelanggara Jasa Internet Indonesia (APJII) pengguna internet di Indonesia paling banyak mengakses konten video, chating, media sosial, serta aktivitas jual beli online (Alfianto, 2019). Staff ahli Bidang Transformasi Digital, Kreativitas dan SDM, serta Kementrian Koordinator Bidang Perekonomian melaporkan pada semester I tahun 2020 terjadi kenaikan transaksi jual beli online sebanyak dua kali lipat dibandingkan periode tahun 2019 (Ramli, 2020). Perilaku pembelian online lebih banyak dilakukan oleh usia antara 18-24 tahun sebanyak 45\%. Lalu diikuti usia 25-34 tahun (41\%), usia 35-44 tahun (8\%), dan sisanya 6\% adalah konsumen berusia di atas 45 tahun (Iswara, 2019). Berdasarkan riset yang dilakukan oleh Katadata Insight Center (KIC) tahun 2019 yang didasarkan jumlah dan nilai transaksi produk. Di mana riset tersebut menjangkau lebih dari 10 juta sampel transaksi di beberapa toko online hasilnya adalah produk fashion menempati posisi pertama yang paling sering dibeli konsumen. Terdapat 30\% transaksi berbelanja online didominasi oleh produk fashion (Pusparisa, 2020).

Banyaknya toko online yang menjual produk fashion, namun hanya terpilih lima toko online setiap tahunnya yang berhak meraih top brand award. Perolehan peringkat top brand award didasarkan pada tiga parameter pengukuran yaitu top of mind share, top of market share, serta top of commitment share. Penilaian parameter top of mind share didasarkan pada awareness konsumen ketika mendengar suatu produk, untuk market share diperoleh pada data penggunaan terakhir konsumen, sedangkan penilaian commitment share didasarkan pada data keinginan konsumen untuk mengkonsumsi di masa mendatang. Dari tahun 2018 sampai 2020 Berrybenka mampu memertahankan peringkat top brand award dan selalu mengalami kenaikan peringkat setiap tahunnya (Top brand award, 2020).

Berdasarkan data Iprice Insight (2021) jumlah pengunjung website Berrybenka mengalami peningkatan setiap tahun. Tahun 2018 jumlah pengunjung sebesar 287.800, tahun 2019 jumlah pengunjung 321.700, dan tahun 2020 jumlah pengunjung website mencapai 352.200. Sebagai brand fashion yang tergolong baru, Berrybenka membuktikan mampu bersaiang dengan brand fashion 
Lutfi Indana \& Anik Lestari Andjarwati. Website Quality, Brand Image, dan E-WOM serta Pengaruhnya terhadap Online Purchase Intention Studi Pengunjung Website Berrybenka

lainnya seperti Zalora, Erigo, Hijup. Dan brand-brand lainnya. Persaingan industri fashion yang semakin ketat, membuat pemasar harus memahami faktor-faktor yang memengaruhi perilaku konsumen dalam memutuskan belanja online. Banyak sekali faktor yang memengaruhi perilaku belanja online seperti yang dikemukan oleh Turban et al. (2015:408). Menurut Turban et al., (2015:408) terdapat lima faktor yang memengaruhi perilaku pembelian konsumen secara online atau niat membeli secara online yaitu karakteristik konsumen (consumer charasteristic), penjual atau perantara (merchat and intermediary related), produk atau pelayanan, sistem penjualan (EC platform) dan lingkungan.

Website quality melrupakan salah satu variabel yang terdapat dalam EC platform yang dapat memengaruhi kepercayaan online. Kemudahan navigasi, tampilan visual, dan informasi desain website juga dapat memengaruhi kepercayaan konsumen untuk membeli produk (Turban et al., 2015:412). Turban et al. (2015:408), dalam model perilaku konsumen online juga menjelaskan bahwa salah satu faktor yang memengaruhi perilaku pembelian konsumen berasal dari faktor produk yaitu citra merek produk. Menurut Schiffman \& Wisenblit (2015:72) citra merek yang positif mengarah pada loyalitas konsumen dan menambah minat konsumen untuk melakukan pembelian. E-WOM juga merupakan faktor pendorong perilaku pembelian konsumen secara online yang bersumber dari faktor lingkungan khususnya lingkungan sosial konsumen (Turban et al., 2015:412). Menurut Nuseir (2019) electronic word of mouth berdampak signifikan terhadap niat beli konsumen. Menurut Christodoulides et al. (2012) terdapat dua jenis ulasan e-WOM yang dapat memengaruhi niat beli konsumen, yaitu ulasan e-WOM positif dan ulasan e-WOM negatif. Saat konsumen yakin dengan ulasan online terdapat kemungkinan untuk meningkatkan kepercayaan konsumen pada e-WOM. Keyakinan dalam pesan online dapat secara positif memengaruhi niat konsumen untuk menulis atau membagikan e-WOM

Adanya perubahan gaya hidup masyarakat yang lebih banyak dilakukan secara online mengakibatkan banyak orang memenuhi kebutuhan dengan melakukan transaksi secara digital. Sehingga sebagai pemasar perlu meningkatkan kualitas layanan online yang dimiliki. Menurut Zeithaml et al. (2002) kualitas layanan elektronik dianggap sebagai sejauh mana situs website memfasilitasi belanja, pembelian dan pengiriman produk dan layanan efektif serta efesien. T. S. Lee et al. (2016) dan Gao \& $\mathrm{Li}$ (2019) menyebutkan bahwa website quality memiliki pengaruh yang signifikan terhadap online purchase intention. Selain website quality, brand image merupakan elemen penting dalam proses pengambilan keputusan pembelian konsumen, brand image yang baik memiliki dampak positif pada niat pembelian secara online (Wang \& Tsai, 2014). Hal itu sesuai dengan Khodabandeh \& Lindh (2020) dan Dash et al. (2021) bahwa brand image memiliki pengaruh signifikan terhadap niat membeli secara online. Menurut Bambauer-Sachse \& Mangold (2011) e-WOM merupakan elemen penting dalam bauran pemasaran online merek apapun, terutama berkontribusi terhadap penciptaan citra merek serta kekuatannya untuk memengaruhi niat beli konsumen (Online Purchase Intention). Nuseir (2019) juga mengatakan bahwa eletronic word of mouth memiliki hubungan yang signifikan terhadap online purchase intention.

Berrybenka merupakan salah satu merek fashion yang ada di Indonesia yang menawarkan berbagai kebutuhan fashion. Produk-produk yang ditawarkan oleh Berrybenka sangat beragam yaitu baju, sepatu, tas, jam tangan, dan aksesoris fashion Tahun 2017 Berrybenka mulai membangun platform website untuk memasarkan produknya. Pada situs website tersebut mereka membuat tagline "Fashion is just a click away" hal ini dapat menyajikan pengalaman belanja yang menyenangkan dan mudah kepada konsumen maupun calon konsumen (Mila, 2017). Sebelum melakukan pembelian, konsumen dapat mengunjungi instagram Berrybenka untuk melihat review dari konsumen lain. Dalam perilaku pembelian konsumen secara online ditemukan ulasan negatif dan positif tentang pengalaman belanja di Berrybenka. Ulasan positif dan negatif konsumen tersebut bisanya dilakukan melalui melalui social media instagram dan melalui website Berrybenka. Menurut data dari google costumer review (2020) yang terdapat dalam website Berrybenka masih ditemukan beberapa ulasan negatif dari konsumen. Kenaikan jumlah ulasan negatif dari konsumen terjadi tahun 2017 sampai dengan 2019. Persentase kenaikan jumlah ulasan negatif yaitu sebesar $11 \%$ setiap tahunnya (Berrybenka.com, 2020). 
Bersasarkan narasi yang telah dijelaskan penelitian ini bertujuan untuk membahas dan menganalisis pengaruh website quality, brand image dan e-WOM terhadap online purchase intention pada pengunjung website Berrybenka.

\section{KAJIAN PUSTAKA DAN PENGEMBANGAN HIPOTESIS}

\section{Website Quality}

Website quality adalah konstruksi multi-dimensi, yang mencerminkan keseluruhan keunggulan situs website penjual online. Secara luas bahwa kualitas situs website mencakup kualitas informasi, kualitas layanan, dan kualitas sistem (Gao \& Li, 2019). Sedangkan pengertian menurut Putra \& Rahmiati (2019) kualitas website adalah keseluruhan kinerja sebuah website untuk memenuhi kebutuhan dan keperluan penggunanya, melalui fitur dan karakteristiknya.

Dalam konteks belanja online, website memainkan peranan yang penting dalam memfasilitasi transaksi antara pembeli dan penjual (Gao \& Li, 2019). Kualitas website berkontribusi pada persepsi pelanggan, kesenangan dan pengalaman yang dirasakan, yang pada gilirannya, akan memengaruhi kepuasan dan niat membeli konsumen (Hsu et al., 2012). Selain itu dengan adanya informasi yang berkualitas tinggi di website mampu memfasilitasi pembeli dengan cepat membuat keputusan pembelian, sehingga membuat website lebih menarik bagi pembeli daripada website lain (Gao \& $\mathrm{Li}$, 2019).

Dimensi website quality yang dikemukan oleh Barnes \& Vidgen (2002) yaitu usability, information quality, service interaction. Menurut Leonidio et al. (2011) indikator dan item yang digunakan untuk mengukur variabel website quality adalah usability, information quality, service interaction quality. Sedangkan menurut Hsu et al. (2012) untuk mengukur website quality menggunakan indikator information quality, system quality, service quality. Sehingga dengan memadukan ketiga pendapat tersebut maka indikator website quality yang digunakan yaitu usability, information quality, service interaction.

\section{Brand Image}

Tjiptono (2011:100) mendefinisikan citra merek sebagai kemampuan merek dalam memenuhi kebutuhan psikologis atau sosial konsumen. Citra merek bisa terbentuk secara langsung melalui pengalaman konsumen dan kontaknya dengan produk, merek, pasar sasaran atau situasi pemakaian dan tidak langsung melalui iklan atau komunikasi. Sedangkan menurut Schiffman \& Wisenblit (2015:133) definisi brand image mengacu pada persepsi konsumen terhadap komponen produk, layanan, merek dan bagaimana konsumen mengevaluasi kualitas penawaran pemasaran.

Jenis citra merek (brand image) menurut Bilson (2011) terdiri atas tiga bagian. Pertama citra pembuat (corporate image), yaitu sekumpulan asosiasi yang dipersepsikan konsumen terhadap perusahaan yang menciptakan barang atau jasa. Kedua citra pemakai (user image), yaitu sekumpulan asosiasi yang dipersepsikan konsumen terhadap pemakai yang menggunakan suatu barang atau jasa. Ketiga citra produk (product image), yaitu sekumpulan asosiasi yang dipersepsikan konsumen terhadap suatu barang atau jasa. Menurut Keller (2013:78-79) terdapat tiga dimensi yang merangkai terbentuknya brand image, antara lain yaitu brand strength, brand favorability, brand uniqueness

Dalam penelitian ini untuk mengukur brand image salah satunya dengan menggunakan teknik free association yang dikemukan oleh Keller (2013:325-335). Langkah pertama yaitu meminta subyek untuk menjawab pertanyaan mengenai pendapat mereka tentang merek Berrybenka. Pertanyaan tersebut diberikan memalui google form yang disebarkan kepada 30 responden sehingga menghasilkan jawaban yang bisa digunakan untuk menjadi indikator dalam penelitian ini yaitu produk Berrybenka memiliki kualitas bagus, harga produk terjangkau, memiliki banyak pilihan model, memiliki desain yang modis, produk terkenal dikalangan pria dan wanita, memiliki banyak pilihan warna, produk Berrybenka sering dipakai oleh kalangan artis. 
Lutfi Indana \& Anik Lestari Andjarwati. Website Quality, Brand Image, dan E-WOM serta Pengaruhnya terhadap Online Purchase Intention Studi Pengunjung Website Berrybenka

\section{E-WOM}

Definisi eletronik word of mouth menurut Schiffman \& Wisenblit (2015:248) yaitu promosi dari mulut ke mulut yang terjadi secara online yang dilakukan melalui jejaring sosial, komunitas merek, blog, ruang obrolan dan tweet. Sedangkan menurut El-Baz et al. (2018) electronic word of mouth dapat didefinisikan sebagai pernyataan postif atau negatif yang dibuat oleh konsumen terhadap suatu produk atau perusahaan melalui internet.

Perkembangan pesat internet dan komunikasi dapat meningkatkan skala dan cakupan eletronik word of mouth. Ulasan online yang berisi informasi baru yang disajikan dari perspektif konsumen yang telah membeli dan menggunakan produk, menjadi sumber informasi utama bagi konsumen lainnya (Lin et al., 2013). Di sisi lain, kehadiran e-WOM sebagai sumber informasi yang berpengaruh bagi konsumen menjadi pendorong untuk meningkatkan dan membangun kredibilitas mereknya. Pada akhirnya, e-WOM menjadi kesempatan pemasar untuk menyimak pemikiran, perasaan, dan preferensi konsumen yang dapat membantu mereka, beradaptasi dengan kebutuhan konsumen. E-WOM dapat melengkapi aktivitas pemasaran merek dan mempromosikan kredibilitas merek, yang dapat memengaruhi niat membeli yang kuat terhadap merek tersebut (El-Baz et al., 2018).

Menurut Lin et al. (2013) dimensi e-WOM yaitu e-WOM quality, e-WOM quantity, sender experties. Sehingga indikator website quality dalam penelitian ini menggunakan e-WOM quality, e-WOM quantity dan sender experties.

\section{Online Purchase Intention}

Liat \& Shi Wuan (2014) mendefinisikan online purchase intention sebagai situasi ketika sesorang memiliki keinginan dan ketertarikan untuk membeli produk atau layanan tertentu melalui website. Lebih lanjut menurut Hsu et al. (2012) pengertian dari online purchase intention adalah kekuatan niat konsumen untuk melakukan perilaku pembelian tertentu melalui internet. Untuk mengukur variabel online purchase intention yang yang mengacu penelitian dari Agmeka et al. (2019), Peña-García et al. (2020), Doan (2020). Item tersebut diantaranya yaitu berniat membeli produk saat ini juga, akan membeli produk di masa mendatang, belanja dapat menghemat waktu, bertransaksi melalui website lebih aman, intensitas mengunjungi website, mengunjungi website saat waktu luang dan mengunjungi website saat mendapat rekomendasi teman.

\section{Pengaruh antar Variabel}

Menurut Turban et al. (2015:408) website quality merupakan salah satu faktor yang memengaruhi perilaku pembelian konsumen secara online. Melalui website Berrybenka pengunjung dapat menikmati fitur-fitur yang lengkap mulai dari informasi ketersediaan produk, costumer service, metode pembayaran, jasa pengiriman, informasi diskon dan fitur pelayanan keluhan pelanggan. Menurut penelitian dari T. S. Lee et al. (2016) dan Gao \& Li (2019) menyebutkan bahwa kualitas website (website quality) memiliki pengaruh yang signifikan terhadap online purchase intention. Namun terdapat hasil penelitian non significant dari Hasanov \& Khalid (2015) bahwa website quality tidak memiliki pengaruh langsung terhadap online purchase intention.

\section{H1: Adanya pengaruh website quality terhadap online purchase intention.}

Turban et al. (2015:408) menjelaskan bahwa salah satu faktor yang memengaruhi online purchase intention yaitu citra merek suatu produk. Menurut penelitian dari Khodabandeh \& Lindh (2020) komitmen konsumen terhadap suatu produk memiliki pengaruh positif dalam penciptaan brand image. Brand image dari Berrybenka diperoleh dari peringkat Top brand award yang berhasil diraih dalam tiga tahun terkahir. Berdasarkan penelitian yang dilakukan oleh Khodabandeh \& Lindh, (2020) dan (Dash et al., 2021) menyatakan bahwa citra merek (brand image) memiliki pengaruh signifikan terhadap online purchase intention. Berbeda dengan penelitian yang dilakukan oleh J. Lee \& Lee (2018) yang menyatakan bahwa kualitas website (website quality) tidak memiliki pengaruh signifikan terhadap online purchase intention).

\section{H2: Adanya pengaruh Brand Image terhadap online purchase intention.}


Sebelum memutuskan untuk membeli produk, konsumen tidak dapat mengetahui tentang pengalaman memakai produk tersebut. Namun dengan mengakses ulasan konsumen lain secara online (e-WOM) dapat merasakan persepsi tentang kualitas produknya (Nuseir, 2019). Menurut Nuseir (2019) e-WOM berdampak signifikan terhadap niat beli konsumen. Jika konsumen yakin dengan e-WOM ada kemungkinan untuk meningkatkan kepercayaan konsumen. Menurut penelitian dari Nuseir (2019) oleh e-WOM berpengaruh signifikan terhadap online purchase intention. Namun berbeda dari penelitian yang dilakukan oleh (Chin \& Lai, 2018) e-WOM tidak berpengaruh signifikan terhadap online purchase intention.

H3: Adanya pengaruh e-WOM terhadap online purchase intention.

Kerangka konseptual penelitian dapat dilihat pada Gambar 1.

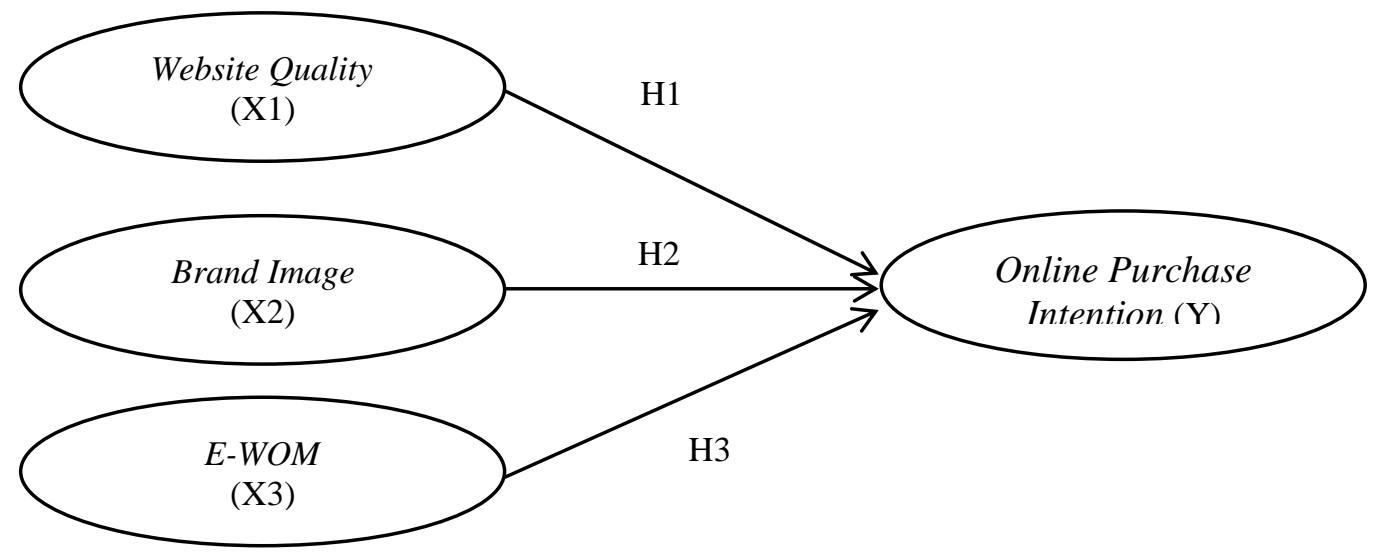

Gambar 1. KERANGKA KONSEPTUAL

\section{METODE PENELITIAN}

Pendekatan penelitian ini yaitu kausal yang digunakan untuk membuktikan hubungan sebab akibat, untuk mengetahui pengaruh antar variabel. Jenis penelitiannya yaitu penelitian konklusif dengan tujuan membuktikan adanya pengaruh dari variabel bebas website quality (X1), brand image (X2) dan e-WOM (X3) terhadap variabel terikat yaitu online purchase intention $(\mathrm{Y})$ kemudian dianalisis secara kuantitatif. Data penelitian menggunakan data primer dari jawaban angket yang diisi responden melalui google form.

Populasi penelitian ini bersifat infinite artinya jumlah populasi yang diteliti tidak diketahui. Karakteristik responden yang diteliti yaitu seseorang yang pernah mengunjungi website Berrybenka dengan kriteria yaitu belum pernah melakukan pembelian produk melalui website yang berusia 18-34 tahun. Teknik pengambilan sampel yang digunakan peneliti yaitu non-probability sampling yaitu menggunakan metode judmental sampling. Setelah itu dilakukan uji validitas dan reliabilitas yang disebarkan kepada 30 responden, untuk mengetahui valid tidaknya instrumen penelitian yang dipakai. Jika instrumen tersebut valid selanjutnya disebarkan kepada 200 responden secara online. Untuk menganalisis data dalam penelitian menggunakan regresi linear berganda dan dianalisis menggunakan program IBM SPSS Statistics versi 26.

\section{HASIL DAN PEMBAHASAN}

\section{Karakteristik Responden}

Responden yang digunakan yaitu pengunjung website Berrybenka yang belum pernah melakukan pembelian produk dengan range usia 18-34 tahun. Deskripsi responden didasarkan pada usia, jenis 
Lutfi Indana \& Anik Lestari Andjarwati. Website Quality, Brand Image, dan E-WOM serta Pengaruhnya terhadap Online Purchase Intention Studi Pengunjung Website Berrybenka

kelamin, pekerjaan, dan pendapatan. Responden didominasi jenis kelamin perempuan dengan jumlah 134 sedangkan jenis kelamin laki-laki berjumlah 66. Berdasarkan usia, usia 22-25 tahun paling mendominasi. Karakteristik responden berdasarkan pekerjaan yang paling terbanyak adalah mahasiswa dengan jumlah 109. Sedangkan berdasarkan pendapatan yang paling mendominasi adalah pendapatan < Rp1.000.000 sebanyak 99. Detailnya karakteristik responden pada tabel 1

Tabel 1.

KARAKTERISTIK RESPONDEN

\begin{tabular}{llcc}
\hline \multicolumn{2}{c}{ Karakteristik Responden } & Jumlah & Presentase \\
\hline Jenis Kelamin & Perempuan & 134 & $67 \%$ \\
& Laki-laki & 66 & $33 \%$ \\
Total & 100 & $100 \%$ \\
Usia & $18-21$ tahun & 70 & $35 \%$ \\
& $22-25$ tahun & 109 & $54.5 \%$ \\
& $26-29$ tahun & 14 & $7 \%$ \\
& $30-34$ tahun & 7 & $3.5 \%$ \\
\hline & Total & 100 & $100 \%$ \\
\hline
\end{tabular}

Sumber: IBM SPSS Statistic 26

Hasil Uji Asumsi Klasik

Tabel 2, menunjukkan hasil dari uji normalitas, multikolonieritas, dan heteroskesdasitas.

Tabel 2.

HASIL UJI ASUMSI KLASIK

\begin{tabular}{|c|c|c|c|}
\hline No & Asumsi Klasik & Hasil Perhitungan & Keterangan \\
\hline 1 & Uji Normalitas & $\begin{array}{l}\text { Kolmogorov-Smirnov Asymp. Sig. (2-tailed) } \\
\text { hasilnya yaitu } 0.080 \text { lebih besar dari dari } 0,05\end{array}$ & Data berdistribusi normal \\
\hline 2 & $\begin{array}{l}\text { Uji } \\
\text { Multikolonieritas }\end{array}$ & $\begin{array}{l}\text { Nilai tolerance dari website quality yaitu } 0,437 \geq 0,1 \text {. } \\
\text { Nilai tolerance brand image yaitu } 0,386 \geq 0,1 \text {. Nilai } \\
\text { e-WOM yaitu } 0,368 \geq 0,01 \text {. }\end{array}$ & $\begin{array}{l}\text { Tidak } \\
\text { multikolonieritas }\end{array}$ \\
\hline 3 & $\begin{array}{l}\text { Uji } \\
\text { Heteroskesdasitas }\end{array}$ & $\begin{array}{l}\text { Nilai sig. (2-tailed) pada X1 sebesar } 0,751 \text { atau }> \\
0,05 \text { pada X2 sebesar } 0,633 \text { atau }>0,05 \text { dan pada.X3 } \\
\text { sebesar } 0,967 \text { atau }>0.05\end{array}$ & $\begin{array}{l}\text { Tidak } \\
\text { heteroskesdasitas }\end{array}$ \\
\hline
\end{tabular}

Sumber: IBM SPSS Statistics 26

\section{Uji Regresi Linier Berganda}

Uji regresi linear berganda digunakan untuk mengetahui pengaruh variabel website quality, brand image, dan e-WOM terhadap online purchase intention pada pengunjung website Berrybenka. Berdasarkan hasil analisis data pada tabel 3 diperoleh model persamaan linear berganda (1) yang menunjukkan model persamaan regresi linear berganda.

$\mathrm{Y}=1.120+0.317 \mathrm{X} 1+0.299 \mathrm{X} 2+0.132 \mathrm{X} 3$

Tabel 3.

HASIL UJI PARSIAL (UJI-t)

\begin{tabular}{clcccc}
\hline \multirow{2}{*}{ Model } & \multicolumn{2}{c}{ Unstandardized Coefficients } & \multirow{2}{*}{ S } & \multirow{2}{*}{ Sig. } \\
\hline \multirow{2}{*}{1} & (Constant) & 1.120 & 2.129 & .526 & .599 \\
& Website Quality & .317 & .068 & 4.685 & .000 \\
& Brand Image & .299 & .102 & 2.938 & .004 \\
& E-WOM & .132 & .069 & 1.907 & .058 \\
\hline
\end{tabular}

Sumber: IBM SPSS Statistics 26 


\section{Uji hipotesis (Uji t)}

Berdasarkan tabel 3, nilai t hitung website quality sebesar 4.685 dan memiliki nilai signifikan sebesar 0,000 yang lebih kecil dari 0,05. Maka, H0 ditolak dan $\mathrm{H} 1$ diterima, sehingga variabel website quality berpengaruh terhadap online purchase intention. Nilai t hitung brand image sebesar 2.938 dan disertai nilai signifikan senilai 0,004 yang memiliki nilai lebih kecil dari 0,05. Artinya, H0 ditolak dan H2 diterima, sehingga variabel brand image berpengaruh terhadap online purchase intention. Nilai $\mathrm{t}$ hitung e-WOM sebesar 1.907 dan nilai Signifikansi sebesar 0,058 > 0,05. Maka H1 ditolak dan H0 diterima, sehingga dapat dijelaskan bahwa variabel e-WOM tidak memiliki pengaruh secara signifikan terhadap online purchase intention $(\mathrm{Y})$.

\section{Pengaruh Website Quality terhadap Online Puchase Intention}

Berdasarkan hasil penelitian menunjukkan adanya pengaruh website quality terhadap online purchase intention secara signifikan. Artinya apabila kualitas website dibangun dengan baik maka akan berpengaruh pada terbangunnya niat membeli konsumen melalui website (online purchase intention). Hasil penelitian ini membuktikan konsep teori dari Turban et al. (2015:408) bahwa kualitas dari website dapat menciptakan niat membeli seseorang secara online.

Hasil penelitian ini mendukung T. S. Lee et al. (2016) dan Gao \& Li (2019), namun tidak mendukung penelitian dari Hasanov \& Khalid (2015). Perbedaan hasil ini kemungkinan terjadi karena adanya perbedaan negara maupun perbedaan obyek penelitian. Hasanov \& Khalid (2015) obyek penelitian adalah makanan organik yang dibeli melalui website sedangkan objek penelitian ini yaitu mengenai brand fashion.

Website Berrybenka menyediakan fitur-fitur yang lengkap seperti pilihan produk, metode pembayaran, metode pengiriman, pentujuk pembelian dan fitur chat 24 jam. Selain itu informasi yang disampaikan melalui website Berrybenka menggunakan Bahasa Indonesia dan bahasa inggris. Dengan adanya fitur chat 24 jam, saat pengunjung website ingin mengajukan pertanyaan sewaktu-waktu akan otomatis terjawab langsung oleh costumer service websitenya. Responden dengan jenis kelamin perempuan dengan usia antara 22-25 tahun yang mendominasi penelitian ini. Perilaku konsumen perempuan cenderung memperhatikan fashion yang dikenakan untuk aktivitas sehari-harinya. Selain itu mereka juga akan selektif dalam memilih toko online tempat mereka belanja. Dari segi fitur-fitur website dan informasinya yang diberikan oleh Berrybenka sudah disesuaikan dengan kebutuhan perempuan. Semakin baik kualitas website yang diberikan maka keinginan konsumen untuk membeli produk tersebut melalui website akan semakin besar.

\section{Pengaruh Brand Image terhadap Online Puchase Intention}

Hasil penelitian menunjukkan adanya pengaruh brand image terhadap online purchase intention secara signifikan. Jika brand image terbangun dengan baik maka akan berpengaruh terhadap peningkatan niat beli konsumen (online purchase intention). Sehingga sesuai dengan konsep teori dari Turban et al., (2015:408) bahwa brand image dapat memengaruhi niat beli melalui website (online purchase intention)

Hasil penelitian tersebut mendukung Khodabandeh \& Lindh (2020) dan Dash et al., (2021) namun hasil tidak mendukung penelitian J. Lee \& Lee (2018). Perbedaan tersebut dapat terjadi karena bahasan mengenai variabel brand image dalam penelitian J. Lee \& Lee (2018) membahas mengenai brand image yang dibagun melalui CSR dari beberapa produk fashion, sedangkan brand image penelitian ini dibangun melalui peringkat Top brand award.

Adanya peningkatan brand image Berrybenka setiap tahun akan mendorong niat membeli para konsumennya. Berrybenka beberapa kali berpartisipasi dalam kegiatan fashion week bergengsi seperti Jakarta fashion week dan internationan fashion week. Selain itu meskipun harga produk Berrybenka terjangkau namun banyak selebriti yang menggunakan produk tersebut. Sehingga dengan adanya citra yang baik terhadap produk maka akan meningkatkan kepercayaan konsumen. Yang menjadi keunikan 
Lutfi Indana \& Anik Lestari Andjarwati. Website Quality, Brand Image, dan E-WOM serta Pengaruhnya terhadap Online Purchase Intention Studi Pengunjung Website Berrybenka

lain dari merek Berrybenka yaitu menawarkan model pilihan baju dengan konsep limited edition yang didesain oleh desainer ternama di Indonesia dan hanya memproduksi dalam jumlah terbatas.

Responden perempuan dengan usia 22-25 tahun yang mendominasi, hal ini dikarenakan responden perempuan cenderung menyukai model pilihan baju yang bervariasi untuk menunjang kebutuhan fashion sehari-harinya. Dengan banyaknya pilihan model yang ditawarkan mulai baju gamis, baju kerja, kemeja, dress dan masih banyak pilihan lainnya yang sangat bervariasi mampu menarik perhatian konsumen. Semakin baik citra merek suatu produk dimata konsumen akan berpotensi untuk meningkatan niat membeli konsumen.

\section{Pengaruh e-WOM terhadap Online Puchase Intention}

Berdasarkan uji yang telah dilakukan menunjukkan tidak adanya pengaruh e-WOM terhadap online purchase intention secara signifikan. Hal ini mengartikan jika kualitas informasi dalam e-WOM mengalami peningkatan maupun penurunan maka tidak memengaruhi niat membeli konsumen melalui webiste (online purchase intention). Hasilnya sesuai dengan teori dari Chin \& Lai (2018) bahwa variabel eletronic word of mouth menunjukan hubungan yang negatif dan non signifikan terhadap online purchase intention.

Hasil ini mendukung penelitian dari Chin \& Lai (2018) namun tidak mendukung penelitian Nuseir (2019) yang menunjukan bahwa variabel e-wom berpengaruh signifikan terhadap online purchase intention. Perbedaan hasil peneltian kemungkinan terjadi karena dalam penelitian Nuseir (2019) meneliti tentang perilaku pembelajaan konsumen perempuan diwilayah Uni Emirat Arab. Dimana para konsumen tersebut sudah paham mengenai konsep e-WOM dan e-WOM yang terdapat dalam penelitian ditampilkan dalam berbagai media sehingga mudah diakses oleh konsumen.

Hasil penelitian ini menunjukkan tidak adanya pengaruh e-WOM terhadap online purchase intention. Sangat dimungkinkan responden belum memahami konsep dari e-WOM dan tidak menampilkan ulasan dari berbagai media Sehingga ulasan yang terdapat dalam sosial media instagram hanya dianggap sebagai foto-foto terkait dengan pengalaman konsumen terhadap Berrybenka. Pembeli cenderung hanya melihat sekilas ulasan tersebut sehingga hal tersebut tidak membekas dalam benak konsumen. Konten-konten ulasan mengenai fashion yang ada di social media instagram juga tidak hanya disampaikan oleh berrybenka saja, namun perusahaan juga memiliki ulasan mengenai produknya. Sehingga dengan banyaknya ulasan yang ada akan membuat konsumen merasa bingung bahkan mengabaikan ulasan tersebut. Karena menurut konsumen ulasan tersebut dianggap tidak penting hal ini yang menyebabkan e-wom tidak berpengaruh terhadap niat membeli konsumen secara online (online purchase intention)

Jika melihat situasi dan kondisi saat khususnya penggunaan media sosial untuk penyampaian e-WOM sangat beragam tidak hanya mengambil melalui Instagram saja. Ulasan tersebut dapat disampaikan melalui youtube, tiktok, twitter, facebook dan ulasan lainnya. Karena dalam penelitian ini hanya menggunakan ulasan dari sosial media instagram sehingga menyebabkan hasil yang tidak signifikan. Berdasarkan jawaban-jawaban dari pertanyaan terbukan yang terdapat dalam angket yang telah disebarkan, konsumen akan melakukan pembelian produk karena kebutuhan dan yan kedua karena faktor diskon. Artinya mereka cenderung lebih menyukai diskon dan citra yang baik dari pada ulasan dari konsumen lain yang ada di Instagram. Sehingga menurut responden ulasan dari konsumen tidak memengaruhi niat membeli konsumen.

\section{KESIMPULAN}

Berdasarkan hasil penelitian dapat disimpulkan bahwa adanya pengaruh positif dan signifikan website quality terhadap online purchase intention pada pengunjung website berrybenka, adanya pengaruh positif dan signifikan brand image terhadap online purchase intention pada pengunjung website berrybenka, tidak adanya pengaruh positif dan signifikan e-wom terhadap online purchase intention pada pengunjung website berrybenka. 
Dalam penelitian ini masih ditemukan beberapa kelemahan peneliti yaitu karakteristik dalam angket online kurang lengkap, tidak menanyakan asal responden, data primer dalam penelitian hanya menggunakan jawaban dari angket online dan tidak melakukan wawancara langsung kepada responden. Untuk selanjutnya disarankan untuk menambahkan karakteristik atau informasi lain dalam angket yang disebarkan seperti pendidikan terakhir responden, status respoden dan karakteristik lainnya sebagai tambahan informasi dan inshight yang lebih mendetail. Hasil penelitian ini secara praktis dapat digunakan sebagai bahan tambahan informasi oleh tenaga marketing, khusunya untuk perusahaan yang bergerak dalam bidang fashion dalam menyusun strategi pemasaran baru. Strategi tersebut berupa peningkatan kualitas website, peningkatan citra merek dan pengembangan kualitas informasi e-WOM untuk mempertahankan pelanggan atau mencari konsumen baru.

\section{DAFTAR PUSTAKA}

Agmeka, F., Wathoni, R. N., \& Santoso, A. S. (2019). The Influence of Discount Framing Towards Brand Reputation and Brand Image on Purchase Intention and Actual Behaviour in Ecommerce. Procedia Computer Science, 161, 851-858. https://doi.org/10.1016/j.procs.2019.11.192

Alfianto, R. (2019). Survei Pengguna Internet Indonesia: Paling Banyak Akses Konten Video. Www.Jawapos.Com. (https://www.jawapos.com/oto-dan-tekno/teknologi/17/05/2019/surveipengguna-internet-indonesia-paling-banyak-akses-konten-video, diakses pada 2 November 2020)

Bambauer-Sachse, S., \& Mangold, S. (2011). Brand Equity Dilution Through Negative Online Wordof-Mouth Communication. Journal of Retailing and Consumer Services, 18(1), 38-45. https://doi.org/10.1016/j.jretconser.2010.09.003

Barnes, S., \& Vidgen, R. (2002). An Integrative Approach to the Assessment of Narcissism. Journal of Electronic Commerce Research, 3(3), 114-127. https://doi.org/10.1080/00223891.2013.770400

Berrybenka.com. (2020). Google Costumer Review. (https://www.google.com/shopping/ratings/account/metrics?q=berrybenka.com\&c=ID\&v=15\& hl=in, diakses pada 10 November 2020)

Bilson, S. (2011). Memenangkan Pasar dengan Pemasaran Efektif dan Profitabel. Jakarta: PT. Gramedia Pustaka Utama.

Chin, T. A., \& Lai, L. Y. (2018). Determinants of Brand Image and Their Impacts on Purchase Intention of Grab. Journal of Arts and Social Sciences, 2(1), 26-36.

Christodoulides, G., Michaelidou, N., \& Argyriou, E. (2012). Cross-National Differences in E-WOM Influence. European Journal of Marketing, 46(11), 1689-1707. https://doi.org/10.1108/03090561211260040

Dash, G., Kiefer, K., \& Paul, J. (2021). Marketing-to-Millennials: Marketing 4.0, Customer Satisfaction and Purchase Intention. Journal of Business Research, 122(February 2020), 608620. https://doi.org/10.1016/j.jbusres.2020.10.016

Doan, T. T. T. (2020). Factors Affecting Online Purchase Intention: A Study of Vietnam online Custumers. Management Science Letters, 10(10), 2337-2342. https://doi.org/10.5267/j.msl.2020.3.001

El-Baz, B. E.-S., Elseidi, R. I., \& El-Maniaway, A. M. (2018). Influence of Electronic Word of Mouth (e-WOM) on Brand Credibility and Egyptian Consumers' Purchase Intentions. International 
Lutfi Indana \& Anik Lestari Andjarwati. Website Quality, Brand Image, dan E-WOM serta Pengaruhnya terhadap Online Purchase Intention Studi Pengunjung Website Berrybenka

Journal of Online Marketing, 8(4), 1-14. https://doi.org/10.4018/ijom.2018100101

Gao, W., \& Li, X. (2019). Building Presence in an Online Shopping Website: The Role of Website Quality. Behaviour and Information Technology, 38(1), 28-41. https://doi.org/10.1080/0144929X.2018.1509127

Hasanov, J., \& Khalid, H. (2015). The Impact of Website Quality on Online Purchase Intention of Organic Food in Malaysia: A WebQual Model Approach. Procedia Computer Science, 72, 382-389. https://doi.org/10.1016/j.procs.2015.12.153

Hsu, C. L., Chang, K. C., \& Chen, M. C. (2012). The Impact of Website Quality on Customer Satisfaction and Purchase Intention: Perceived playfulness and perceived flow as mediators. Information Systems and E-Business Management, 10(4), 549-570. https://doi.org/10.1007/s10257-011-0181-5

Iprice Insight. (2021). Peta E-commerce Indonesia. (Https://Iprice.Co.Id/Insights/Mapofecommerce/. https://iprice.co.id/insights/mapofecommerce/, diakses pada 8 Desember 2020)

Iswara, A. J. (2019). Belanja Online di indonesia dalam Angka. Good News From Indonesia. (https://www.goodnewsfromindonesia.id/2019/03/26/belanja-online-di-indonesia-dalamangka\#: :text=Untuk pembagian usia\%2C sesuai dugaan,berusia di atas 45 tahun, dikases pada 18 November 2020).

Jayani, D. H. (2020). Orang Indonesia Habiskan Hampir 8 Jam Untuk Berinternet. Databoks. (https://databoks.katadata.co.id/datapublish/2020/02/26/indonesia-habiskan-hampir-8-jamuntuk-berinternet, diakses pada 14 November 2020)

Keller, K. L. (2013). Strategic Brand Management; Building, Measuring, and Managing Brand Equity. (Fourth Edi). United States: Pearson Education Inc.

Khodabandeh, A., \& Lindh, C. (2020). The Importance of Brands, Commitment, and Influencers on Purchase Intent in The Context of Online Relationships. Australasian Marketing Journal, 29(2), 177-186. https://doi.org/10.1016/j.ausmj.2020.03.003

Lee, J., \& Lee, Y. (2018). Effects of Multi-brand Company's CSR Activities On Purchase Intention Through A Mediating Role of Corporate Image and Brand Image. Journal of Fashion Marketing and Management, 22(3), 387-403. https://doi.org/10.1108/JFMM-08-2017-0087

Lee, T. S., Md Ariff, M. S., Zakuan, N., \& Sulaiman, Z. (2016). Assessing Website Quality Affecting Online Purchase Intention of Malaysia's Young Consumers. Advanced Science, Engineering and Medicine, 8(10), 836-840. https://doi.org/10.1166/asem.2016.1937

Leonidio, U. da C., Montezano, R. M. da S., \& Carvalho, F. A. de. (2011). Evaluation of the Perceived Quality of the Website of an Online Bookstore: an Empirical Application of the Carnes and Vidgen Model. JISTEM Journal of Information Systems and Technology Management, 8(1), 109-130. https://doi.org/10.4301/s1807-17752011000100006

Liat, C. B., \& Shi Wuan, Y. (2014). Factors Influencing Consumers' Online Purchase Intention: A Study among University Students in Malaysia. International Journal of Liberal Arts and Social Science, 2(8), 122-133. www.ijlass.org

Lin, C., Wu, Y.-S., \& Chen, J.-C. V. (2013). Electronic Word-of-Mouth: The Moderating Roles of Product Involvement and Brand Image. Proceedings of 2013 International Conference on Technology Innovation and Industrial Management, 29-47. 
Mila. (2017). Situs Belanja Online Fashion Ternama, Berrybenka. Hemat.Id Artikel. (https://blog.hemat.id/situs-belanja-online-fashion-ternama-berrybenka/, diakses pada 8 juni 2021)

Nuseir, M. T. (2019). The Impact of Electronic Word of Mouth (e-WOM) on the Online Purchase Intention of Consumers in the Islamic Countries - a case of (UAE). Journal of Islamic Marketing, 10(3), 759-767. https://doi.org/10.1108/JIMA-03-2018-0059

Peña-García, N., Gil-Saura, I., Rodríguez-Orejuela, A., \& Siqueira-Junior, J. R. (2020). Purchase Intention and Purchase Behavior Online: A cross-cultural approach. Heliyon, 6(6), 1-11. https://doi.org/10.1016/j.heliyon.2020.e04284

Pusparisa, Y. (2020). Riset KIC: Produk Busana Paling Diburu Konsumen E-Commerce. Databoks. (https://databoks.katadata.co.id/datapublish/2020/08/07/riset-kic-produk-busana-paling-diburukonsumen-e-commerce, diakses pada 2 November 2020)

Putra, F. S., \& Rahmiati. (2019). Pengaruh Website Quality terhadap Online Booking Intention dengan Mediasi E-Trust pada Pengguna Traveloka Di Kota Padang. Jurnal Kajian Manajemen Dan Wirausaha, 01, 59-72.

Ramli, R. R. (2020). Transaksi E-Commerce Naik 2 Kali Lipat, Tetapi. Www.Kompas.Com. (https://money.kompas.com/read/2020/10/19/120631626/transaksi-e-commerce-naik-2-kalilipat-tetapi, diakses pada 3 November 2020)

Schiffman, L. G., \& Wisenblit, J. L. (2015). Consumer Behavior, Eleventh Edition. In Consumer Behavior (11th editi, Issue 6). United States: Pearson Education Limited.

Tjiptono, F. (2011). Seri Manajemen Merek 01 - Manajemen Dan Strategi Merek. Yogyakarta: Andi.

Top brand award. (2020). Top Brand Index. (https://www.topbrand-award.com/tentang-top-brandaward/, diakses pada 3 November 2020)

Turban, E., King, D., Lee, J. K., Liang, T.-P., \& Turban, D. C. (2015). Electronic Commerce - A Managerial and Social Perspective. Springer.

Wang, Y., \& Tsai, C. (2014). The Relationship between Brand Image and Purchase Intention: Evidence from Award Winning Mutual Funds. The International Journal of Business and Finance Research, 8(2), 27-40.

Zeithaml, V. A., Parasuraman, A., \& Malhotra, A. (2002). Service quality delivery through web sites: A critical review of extant knowledge. Journal of the Academy of Marketing Science, 30(4), 362-375. https://doi.org/10.1177/009207002236911 